\title{
USABILITY TESTING OF GOOGLE CLOUD APPLICATIONS: STUDENTS' PERSPECTIVE
}

\author{
Abdullah Alqahtani iD \\ Imam Abdulrahman Bin Faisal University, Dammam (Saudi Arabia) \\ asalqabtani@iau.edu.sa
}

Received October 2018

Accepted March 2019

\begin{abstract}
Modern information and communication technologies affect all areas of life significantly, including education and learning. Cloud storage tools are one of the forms of modern information technologies that are employed to serve the educational process. The current research aims to study the use of Google cloud applications (Google Classroom, Google Plus, and Google Drive) in education and to determine the most appropriate Web-based training environment in view of the level of usability. The experimental method was applied in this study using a sample of 200 students from Imam Abdul Rahman bin Faisal University. The current research found that there was some convergence in the usability of the three environments. The results of the study indicated that the environment of Google Classroom has the highest usability value (86.45) and also showed statistically significant differences in scholastic achievement in the application of Google Classroom in the educational process.
\end{abstract}

Keywords - Web-based learning environments, Distance learning, Google cloud applications, Usability test.

\section{To cite this article:}

Alqahtani, A (2019). Usability testing of Google Cloud applications: Students' perspective. Journal of Technology and Science Education, 9(3), 326-339. https://doi.org/10.3926/jotse.585

\section{Introduction}

E-learning is a web-based learning ecosystem bringing several stakeholders together with technology and processes. With the new revolution of communication and Internet devices such as smartphones, laptops, tablets, and computers, e-learning use and practice has become a requirement around the world. There are several examples of global e-learning platforms, such as Khan Academy, Udacity, Coursera, EDX, and Massive Open Online Courses (MOOCs) (Alraimi, Zo \& Ciganek, 2015; Chauhan, 2014; Cidral, Oliveira, Di Felice \& Aparicio, 2018).

Cloud computing is a new trend in the use of digital computers across the Web, which represents a research variable that education science uses for education and learning areas. The Internet has a significant quantity of free software that can be invested and used in education. The Google for education initiative, embodied in Google cloud applications that provide cloud storage space, enables individuals to place and store their knowledge and skills on a service provided by the cloud environment, as well as on 
electronic platforms that can be used in content management, e-learning courses, and learning process management (Halash, 2013).

A study by Wul, Wang, Huang and Ciung (2012) illustrated that Google cloud education applications have many characteristics, causing many educational systems and institutions to select these applications for distance learning. They can be used in classrooms and educational institutions in several forms such as document creation, editing and data sharing, as well as offering effective control tools for easy sharing and compatibility. One of the advantages of these applications that a cloud requires only a small space on a storage disk, in addition to providing access to all the applications with a single Google account and from any device connected to the Internet (Ovadia, 2011).

Blended learning is a mixed-learning environment in which teachers use e-learning with traditional class teaching activities. It can be described as the combination of face-to-face teaching with online education (Oliver, 2018). E-learning helps learners overcome the limitations of time and place. Mobile services could serve as effective learning gadgets through third-generation (3G) technology (J. Huang, Lin \& Chuang, 2007). Mobile learning (M-learning) is a term referring to learning through the use of a mobile device. It focuses on learning through social and content interactions using personal electronic devices (Crompton, 2013). The new communication devices allow learners to access knowledge from anywhere and anytime. Crompton and Burke (2018) investigated the use of mobile learning in higher education. Their results indicated that the majority of the studies focused on the impact of mobile learning on student achievement. Teaching language was the most often researched subject matter domain. The largest age group of mobile users was 18-29 years old, which is the common age of higher education students. The higher education community is encouraging all stakeholders to expand their learning opportunities beyond the classroom with mobile learning.

Learning management system (LMS) software is one of the main learning tools used with education technology. There are several examples of LMSs, such as Moodle, Sakai, Blackboard, Edmodo, and Google Classroom. Google Classroom is considered one of the most speedily implemented tools in higher education (Jakkaew \& Hemrungrote, 2017; Kumar \& Bervell, 2019).

There are many Google applications, such as Google Drive, that can be used in the educational process, particularly in the case of remote training. Google Drive is a cloud storage service that enables the storage and sharing of individual files or entire folders with specific people or with all learners in the classroom, as well as creating and responding to comments from them (Almishiki, 2017). It can accommodate PDF files, Microsoft Office files, videos, image files, and Google presentations; additionally, users can make adjustments to these files and access the latest version from anywhere, synchronously or asynchronously.

Google Classroom is another Google application (Hammadi, 2017) with an e-learning system based on blended learning, which is a principle that focuses on integrating learning in a classroom with a teacher and learning via the Internet. Teachers and trainers can use it to facilitate the classroom teaching process by using the teaching techniques for learning and training that are available on the system, such as homework, marks, communication, archived lessons, mobile learning, and scholastic evaluations. The Google Plus application can also be used for the educational process. It is a social network that can be customized to encourage students to discuss and share their knowledge. Students could take advantage of several features of Google Plus, such as Circles, Hangout video calls, Spark interests, Huddle group talks, and forums (Ovadia, 2011; Bai, Shen, Chen \& Zhou, 2011).

\section{Literature Review}

Lahoti and Ramteke (2004) pointed out the concept of Web-based training environments as Web-based environments that represent a widespread domain with effective methods for improving learning outcomes. Investment in Web networks and technology applications, which represent part of the fifth generation of the Internet, has many advantages in the application of the educational process and is supported by a number of theories, including social construction theory. Web-based training 
environments were defined by Halash (2013) as enabling individuals to place and store their knowledge and skills on electronic platforms that can be used in content management, e-learning courses, and learning management and training. This is due to the ability of these e-cloud platforms to contain a large amount of verbal and visual digital knowledge that can be used anytime and anywhere synchronously and asynchronously, based on the nature of the work determined by the users.

Google cloud applications are free applications that consist of a set of collaborative and sharing tools and solutions provided by Google that can be utilized greatly by educators in the field of education (Google, 2009). There are many advantages to adopting Google applications in education. Google applications achieve the first goal of education, which is sharing, as both the Google website and the documentcreation tools enable real-time editing and collaboration, as well as provide effective control tools for easy sharing in order for students to cooperate and share collected information about the same subject. Google applications could facilitate tasks such as writing articles and scheduling appointments for the class (Tugrul, 2012). A group of students can work on a task in Google Docs, and everyone in the group can see changes in real time instead of waiting to receive the changes via e-mail, which helps to save time that can then be used for teaching or learning (Sherer \& Shea, 2011).

One of the most prominent features and advantages of Google Classroom is the "Homework" feature, which allows students to access their homework, complete it, send it to the teacher electronically via a direct connection, and receive their marks. This service provides many ways to give students their marks electronically and allows the students to view their marks directly (Fralinger \& Owens, 2009; Krauskopf, Zahn \& Hese, 2012). The service is characterized by having an application on smartphones, enabling increased and faster access for students and teachers, saving time by allowing the students to access the material or the class required via their phones. Moreover, teachers can establish a new class within a few seconds, and the system can then generate a small code consisting of letters and numbers to be published for the students to use in the classroom. In addition, the School Evaluate feature allows students and teachers to access the due dates for homework, tests, and other important details and directly import them to e-mail and the calendar available on mobile phones (Schmid, Bernard, Borokhovski, Tamim, Abrami, Surkes et al., 2014).

In this context, the results of several studies, including the work of Doan (2014), confirmed that e-learning would become more effective when introduced in the future via cloud computing applications. Bhatia and Lala (2012) asserted the effective impact of cloud computing in the study of various courses, and the results of the study by Doelitzscher, Sulistio, Reich, Kuijs and Wolf, (2011) confirmed that the cloud environment that was designed played a major role in developing support for learners. The studies by Aaron and Roche (2012), Bagish (2014), and Alhamdi and Khaparde (2014) pointed to the positive impact of cloud computing on learners' development of practical skills in various courses, particularly cooperation and sharing of knowledge. There is increasing interest of many universities to use the cloud computing environment with their programs and educational activities to increase communication and sharing among learners.

According to Ercan (2010), Lahoti and Ramteke (2014), and Femandez, Peralta, Benitez and Herrera (2014), the cloud computing environments represented by Google Cloud applications show the widespread area that achieves the objectives of e-learning and education technology because of its effective ways to achieve learning outcomes through the utilization of Web networks and technology applications to provide better communication and knowledge sharing.

On the other hand, several studies and extensive research have examined the relationship between the patterns and variables of Web-based learning design and their usability, including the works of Carmel and John (2009), Khamis and Almuatasim (2011), and Fang and Holsapple (2007). Furthermore, Van and Ling (2008) investigated the impact of the interaction between the design of the elements on a website interface and usability in terms of the ease of navigation for the user and rapid access to its portals. Khalifa and Abdumunim's (2016) study indicated that the success of the cloud computing environment depends on the attitude of the learner toward this environment. The study reported that there may be a link between success and the learner's character traits with regard to his or her high or low level of 
acceptance, which affects the learning outcomes. This was also reported in a study by Kessler (2012), which recommended studying the relationship between cloud computing and usability with the purpose of encouraging flexible educational practices because research on the relationship between cloud computing and usability is still limited and requires further studies.

In the same context, Al-Mani's (2005) study recommended that teachers should identify students' preferences for learning methods and prepare their lessons accordingly; moreover, the teaching methods followed by teachers need to be diverse to ensure the satisfaction of all the students' needs and dispositions. The study also recommended including educational stimuli that increase the students' interest in learning.

Furthermore, the studies by Carmel and John (2009) and Mariya (2011) pointed to examining and analyzing learners' abilities and attitudes toward using cloud computing environments to enable learners to accept and assimilate both the educational environment and the educational content involved in terms of use and application because usability leads to integration in learning tasks, which affects learning outcomes.

To ensure the effectiveness of the cloud computing environment, research on education technology should not neglect the study and analysis of learners' abilities to use cloud computing effectively to achieve the desired learning outcomes. Usability is considered a prerequisite for ensuring the success of the educational system (Kessler, 2012). Moreover, the study by Mariya (2011) pointed to the existence of interaction between the cloud computing environment and the usability of that environment, which appeared to be a factor in in the high scholastic achievement of students. In addition, Khamis (2009) stated that the ability to learn showed the user's ability to use and interact with the system quickly and easily to accomplish the required tasks efficiently and effectively. It is important to do so with the fewest errors, which is a key variable in the quality control of the cloud computing environment and its effectiveness in learning.

Al-Maroof and AlEmran's (2018) study reported the need for more investigation of the acceptance and behavioral intention of Google Classroom in higher education. Their study also reported that there is a gap in the current literature about the use of Google Classroom worldwide.

In general, cloud computing can be classified as one of the interesting topics in current education research. This concept was announced for first time by John McCarthy in 1961, who mentioned that computing would be a public service (Wheeler \& Waggener, 2009). Shi, Yang, Yang and Wu (2014) investigated cloud computing and reported five main areas. First are conceptual and pedagogical aspects, which involve investigating the meaning of cloud computing. The second area is educational applications; this aspect focuses on how cloud-based services are applied to improve teaching and learning. The third area is processing of information and resources. This area includes access, sharing, storage, backup, and recovery. Then, there are pros and cons of cloud computing in education, as well as database management systems integrated with cloud-based services (Shi et al., 2014). This investigation could be classified under the second aspect, educational applications. It will study the impact of Google cloud applications and how they could enhance teaching and learning.

\section{Purpose of the Study}

Based on what has been shown in previous studies, there is a lack of studies addressing the adoption of cloud storage tools within the Saudi higher education system. There is a current need to study the usability of Google cloud applications to better understand the acceptance of those applications. In addition, there is a growing interest in e-learning systems in Saudi Arabia, which creates a need for investigative research to address the current gap in knowledge about the impact of using Google cloud applications (Google Classroom, Google Plus, Google Drive) in education.

It is important to determine the most appropriate cloud environment from among the three environments included in the current research (Google Classroom, Google Plus, and Google Drive) in the framework of Web-based distance education by investigating the level of usability with the students at Imam 
Abdulrahman Bin Faisal University. Therefore, it was necessary to conduct the current research to determine the most appropriate cloud training environments for distance learning due to a lack of research in this regard. The current research aims to determine the most appropriate Web-based learning environment using Google applications and their relevance to distance learning from the perspective of the level of usability. It also aims to measure the impact of different cloud learning environments (Google Classroom, Google Plus, and Google Drive) on students' achievements compared to traditional environments.

Accordingly, the current research seeks to answer the following main questions:

1. What is the level of usability of Google Cloud applications (Google Drive, Google Plus, and Google Classroom) when used in education from the students' perspective?

2. What is the impact of using Google Cloud applications (Google Drive, Google Plus, and Google Classroom) on learning achievements?

\section{Methodology}

This section details the research design, including its organization, methodology, and relevant evaluation procedures. The research approach for this investigation is experimental. This approach is used to measure the impact of specified phenomena, and it can be used to draw conclusions about cause and effect (Bell, 2014). The experimental approach is applicable for research relating to phenomena from several disciplines (Kothari, 2004). This research uses the experimental approach to measure the impact of search variables represented in Google applications (Google Plus, Google Drive, and Google Classroom) on learning outcomes, and it measures their relevance in terms of usability levels.

\subsection{Participants}

The design involved three experimental groups and one control group. The study sample of 200 students was divided randomly into four groups, with 50 students per group. The participants of this study were aged 21 to 24 years old; 110 of them were female students and 90 were male students.

The first group of students studied using Google Drive, the second group of students studied using Google Plus, the third group of students studied using Google Classroom, and the fourth group, the control group, studied in the traditional way to measure the impact of Google applications compared with traditional teaching methods. The sample included students of both sexes from various disciplines in courses on learning and e-learning technology. All participants were undergraduate students at Imam Abdulrahman bin Faisal University and were enrolled in the course "Multimedia and Instructional Technology." All participants had sufficient computer skills to work with cloud applications. This course is a core unit for all students. The first meeting with each group included sufficient training for using each tool in the course to ensure the students had the required skills for using those cloud applications.

The practices of this study included adopting Google cloud applications into the teaching process. This included using cloud applications (Google Plus, Google Drive, and Google Classroom) to share files, have online discussions, share ideas, share videos, and submit projects and online assessments.

\subsection{Data Collection and Analysis}

This section details the research practice and process of data collection and analysis.

\subsubsection{Level of usability of Google Cloud applications}

To answer the first question, it was necessary to consider the usability of the Google applications. Based on the interaction of system interfaces, Khamis (2009) defined usability as the ability of the learner to interact with the system easily and quickly via the design of the interaction interface to accomplish the required educational tasks with fewer errors. With regard to the general concept, Alon and Herath (2014) described usability as the user's ability to access the material or to satisfy his or her actual needs on the system. If the 
user fails to find what he or she wishes, he or she might abandon the system entirely in search of another system that achieves the requirements of simplicity, clarity, and the fastest and easiest access to the desired scientific subject. Therefore, usability is a prerequisite for users in Web-learning environments.

To investigate the usability of Google applications, this study adopted the System Usability Scale (SUS), which is a 10-item scale developed by John Brooke in 1986. SUS is a widely used scale that provides software developers with an evaluation of their products and user interfaces. SUS consists of 10 phrases that are ranked on a five-point Likert scale measuring strength of agreement. The final score can range from 0 to 100; higher scores designate better usability (Martins, Rosa, Queiros, Silva \& Rocha, 2015; Bangor, Kortum \& Miller, 2008). The total score for the SUS is calculated via the formula defined by Brooke (1996). Firstly, for the odd items, 1 is subtracted from the user's score. Secondly, for the even-numbered items, the user's score is subtracted from 5. Finally, the converted scores for each user are added and the total is multiplied by 2.5. This converts the range of possible values from 0 to 100 (Martins et al., 2015; Brooke, 1996).

Figure 1 shows the applicable study procedures to answer the first question. The SUS test was applied to the experimental groups, and the level of usability of each application was compared. The SUS will be investigated for the three groups that studied using Google applications (experiment groups). The control group will not be investigated within this analysis because it is not related to the first research question.

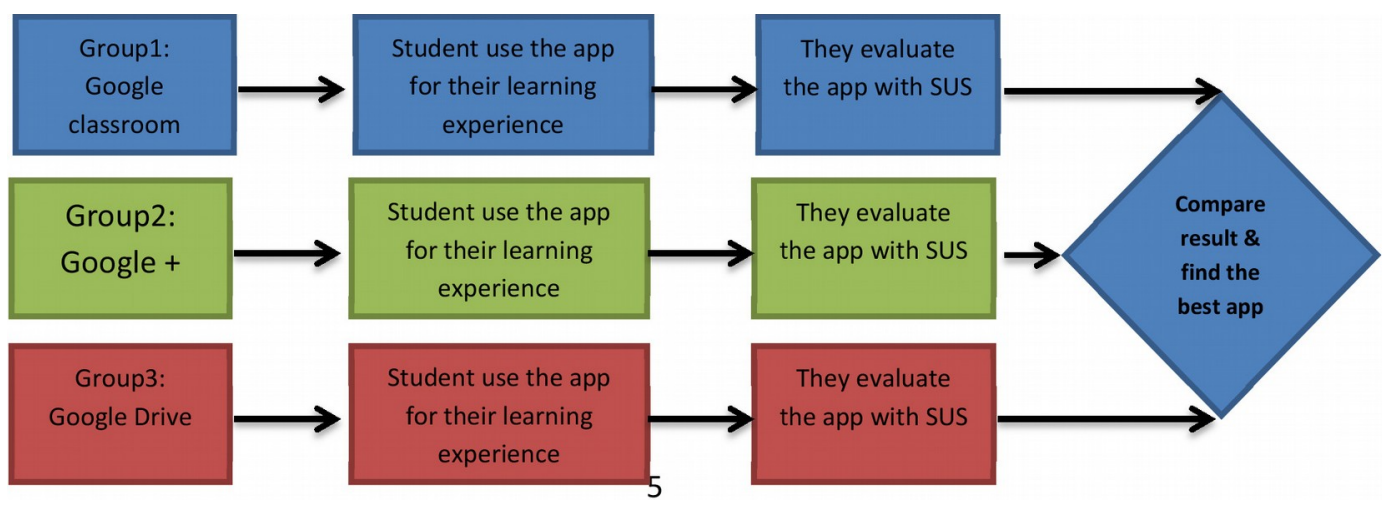

Figure 1. Usability testing process

\subsubsection{The Impact of Using Google Cloud Applications}

To answer the second question, it was necessary to study the impact of Google applications on students' academic achievements. The results of the post-test in the three experimental groups and the control group were compared. The participants studied the same course in the learning and e-learning technology. Both the pre-test and the post-test examined the knowledge of the students in the investigated course. The tests were simple, corresponding, and used multiple choice questions to test the knowledge and skills of students before and after the course.

To ensure the reliability of a sample, there should be no differences between the experimental and control groups. A pre-test of the selected sample was conducted in all the groups to ensure the validity of the study results (Bryman \& Cramer, 2012; Dawson, 2009). This test was conducted at the beginning of the experiment to ensure that there was no bias between the groups.

\begin{tabular}{|l|r|r|r|r|r|}
\hline & Sum of Squares & \multicolumn{1}{|c|}{ df } & Mean Square & \multicolumn{1}{c|}{ F } & Sig. \\
\hline Between Groups & 143.45 & 3 & 47.81 & \multirow{2}{*}{1.16} & .32 \\
\hline Within Groups & 8030.03 & 196 & 40.97 & & \\
\hline Total & 8173.48 & 199 & & & \\
\hline
\end{tabular}

Table 1. ANOVA test results 
An ANOVA test was used to test the differences in the averages among the groups. The results in Table 1 show that there were no statistical differences in the results of the students in the three experimental groups and the control (Sig > 0.05). This means the sample was homogeneous and there were no differences between the skills of students in the different groups. A post hoc test was applied to compare each group with the other groups. The results in Table 2 show no statistically significant differences among the groups in the pre-test. The table compares each group with each of the other groups to identify any individual differences between any two groups.

Figure 2 explains the research process for investigating the second question of this study. It summarizes the experience starting from the pre-test exam, after which the students were randomly distributed into four groups. After that, the experimental groups studied the course by adopting Google apps. The control group used traditional learning experiences to complete their course. At the end, the students had to take a post-test, and the differences between their performances were compared to answer the second question.

\begin{tabular}{|c|c|c|c|c|c|c|}
\hline \multicolumn{7}{|c|}{ Scheffe } \\
\hline \multirow[b]{2}{*}{ (I) VAR00002 } & \multirow[b]{2}{*}{ (J) VAR00002 } & \multirow{2}{*}{$\begin{array}{c}\text { Mean Difference } \\
(\mathrm{I}-\mathrm{J})\end{array}$} & \multirow[b]{2}{*}{ Std. Error } & \multirow[b]{2}{*}{ Sig. } & \multicolumn{2}{|c|}{ 95\% Confidence Interval } \\
\hline & & & & & Lower Bound & Upper Bound \\
\hline \multirow{3}{*}{ Google+ } & Google Drive & 2.17 & 1.28 & .41 & $-1.43-$ & 5.77 \\
\hline & $\begin{array}{l}\text { Google } \\
\text { Classroom }\end{array}$ & 1.78 & 1.28 & .58 & $-1.82-$ & 5.38 \\
\hline & Control Group & .81 & 1.28 & .94 & -2.79 & 4.41 \\
\hline \multirow{3}{*}{ Google Drive } & Google+ & $-2.17-$ & 1.28 & .41 & $-5.77-$ & 1.43 \\
\hline & $\begin{array}{l}\text { Google } \\
\text { Classroom }\end{array}$ & $-.39-$ & 1.28 & .99 & $-3.99-$ & 3.21 \\
\hline & Control Group & $-1.36-$ & 1.28 & .77 & $-4.96-$ & 2.24 \\
\hline \multirow{3}{*}{$\begin{array}{l}\text { Google } \\
\text { Classroom }\end{array}$} & Google+ & $-1.78-$ & 1.28 & .58 & $-5.38-$ & 1.82 \\
\hline & Google Drive & .39 & 1.28 & .99 & $-3.21-$ & 3.99 \\
\hline & Control Group & $-.97-$ & 1.28 & .90 & $-4.57-$ & 2.63 \\
\hline \multirow{3}{*}{ Control Group } & Google+ & $-.81-$ & 1.28 & .94 & $-4.41-$ & 2.79 \\
\hline & Google Drive & 1.36 & 1.28 & .77 & $-2.24-$ & 4.96 \\
\hline & $\begin{array}{l}\text { Google } \\
\text { Classroom }\end{array}$ & .97 & 1.28 & .90 & $-2.63-$ & 4.57 \\
\hline
\end{tabular}

Table 2. Multiple Comparisons result for the pre-test

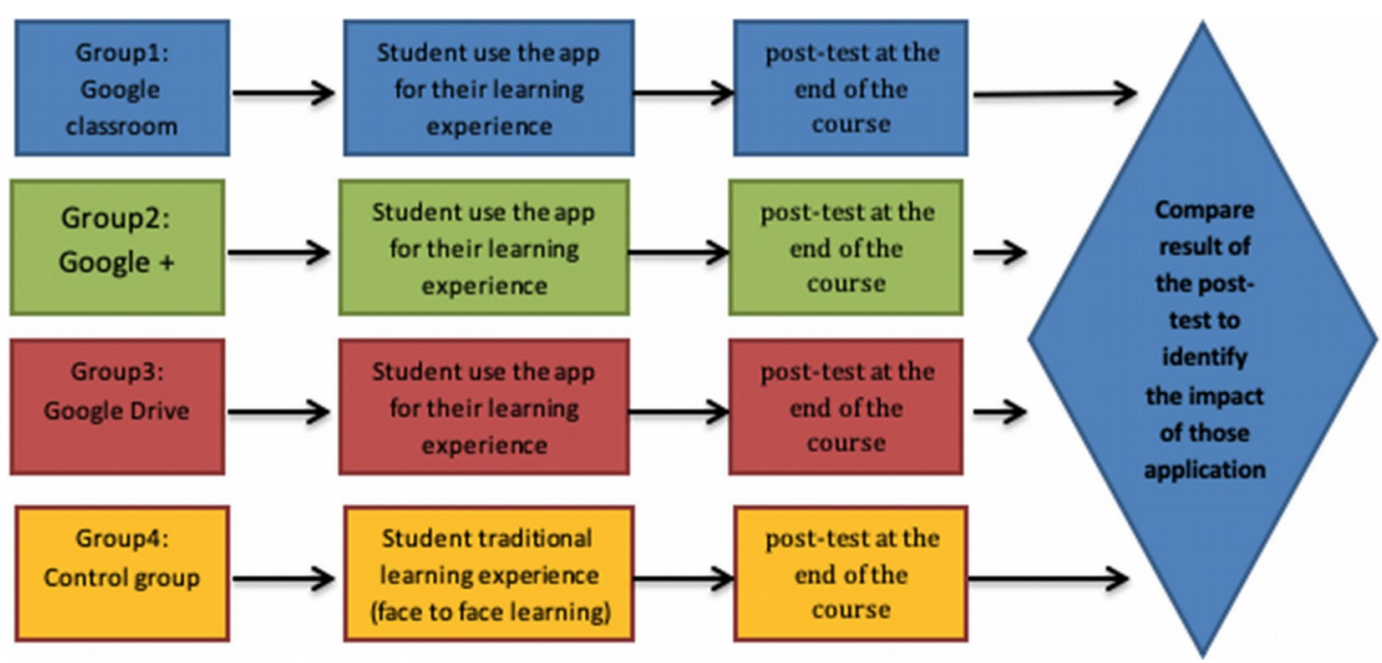

Figure 2. The process of identifying the impact of using Google Cloud applications 


\section{Result}

This section presents the results obtained in this study.

\subsection{The Usability Scale}

This section is intended to answer the first research question. Table 3 presents the SUS test results for the three applications. It displays the sum of the points obtained for each phrase on the scale for each group and presents the average answers and standard deviation for each phrase. The table shows a general convergence of the answers of the experimental groups concerning the scale's phrases, reflecting a convergence of the three applications with regard to the level of usability.

Extrapolating the data in Table 4 shows the students' responses to the SUS items. After applying the statistical treatments and the SUS rules to the scale, the overall score for the scale of usability for the students who studied using the Google Drive environment was 3837.5, which represents the total results of all the students in the experimental group, or an average equivalent of 76.75 out of 100 points on the SUS. This score is acceptable because it is above the minimum (68). Based on the classification of the score in Figure 3, students classified Google Drive as good.

\begin{tabular}{|c|c|c|c|c|c|c|c|c|c|c|}
\hline \multirow[b]{2}{*}{$\mathbf{N}$} & \multirow[b]{2}{*}{ Phrase } & \multicolumn{3}{|c|}{ Google Class room } & \multicolumn{3}{|c|}{ Google Plus } & \multicolumn{3}{|c|}{ Google Drive } \\
\hline & & Score & Mean & $\begin{array}{l}\text { Std. } \\
\text { D }\end{array}$ & Score & Mean & $\begin{array}{l}\text { Std. } \\
\text { D }\end{array}$ & Score & Mean & $\begin{array}{l}\text { Std. } \\
\text { D }\end{array}$ \\
\hline 1 & $\begin{array}{l}\text { I think that I would like to use this } \\
\text { system frequently. }\end{array}$ & 225 & 4.50 & 0.67 & 220 & 4.40 & 0.67 & 210 & 4.20 & 0.80 \\
\hline 2 & $\begin{array}{l}\text { I found the system unnecessarily } \\
\text { complex. }\end{array}$ & 71 & 1.42 & 0.67 & 81 & 1.62 & 0.85 & 88 & 1.76 & 0.87 \\
\hline 3 & $\begin{array}{l}\text { I thought the system was easy to } \\
\text { use. }\end{array}$ & 225 & 4.50 & 0.67 & 221 & 4.42 & 0.67 & 216 & 4.32 & 0.65 \\
\hline 4 & $\begin{array}{l}\text { I think that I would need the } \\
\text { support of a technical person to be } \\
\text { able to use this system. }\end{array}$ & 81 & 1.62 & 0.66 & 87 & 1.74 & 0.72 & 94 & 1.88 & 0.68 \\
\hline 5 & $\begin{array}{l}\text { I found the various functions in } \\
\text { this system were well integrated. }\end{array}$ & 224 & 4.48 & 0.67 & 220 & 4.40 & 0.75 & 212 & 4.24 & 0.91 \\
\hline 6 & $\begin{array}{l}\text { I thought there was too much } \\
\text { inconsistency in this system. }\end{array}$ & 75 & 1.50 & 0.67 & 89 & 1.78 & 1.05 & 96 & 1.92 & 1.08 \\
\hline 7 & $\begin{array}{l}\text { I would imagine that most people } \\
\text { would learn to use this system very } \\
\text { quickly. }\end{array}$ & 213 & 4.26 & 0.94 & 176 & 3.52 & 1.29 & 176 & 3.52 & 1.29 \\
\hline 8 & $\begin{array}{l}\text { I found the system very } \\
\text { cumbersome to use. }\end{array}$ & 75 & 1.50 & 0.67 & 89 & 1.78 & 1.05 & 91 & 1.82 & 1.04 \\
\hline 9 & $\begin{array}{l}\text { I felt very confident using the } \\
\text { system. }\end{array}$ & 222 & 4.40 & 0.80 & 216 & 4.32 & 0.89 & 208 & 4.16 & 1.09 \\
\hline 10 & $\begin{array}{l}\text { I needed to learn a lot of things } \\
\text { before I could get going with this } \\
\text { system. }\end{array}$ & 76 & 1.52 & 0.67 & 100 & 2 & 1.29 & 118 & 2.36 & 1.54 \\
\hline
\end{tabular}

Table 3. SUS results based of the scale of by Brooke (1996)

\begin{tabular}{|l|r|r|c|}
\hline & Total Score & Score Mean SM & Rating \\
\hline Google Class room & 4322.5 & 86.45 & Best Imaginable \\
\hline Google Plus & 4017.5 & 80.35 & Excellent \\
\hline Google Drive & 3837.5 & 76.75 & Good \\
\hline
\end{tabular}

Table 4. SUS rating for each application 


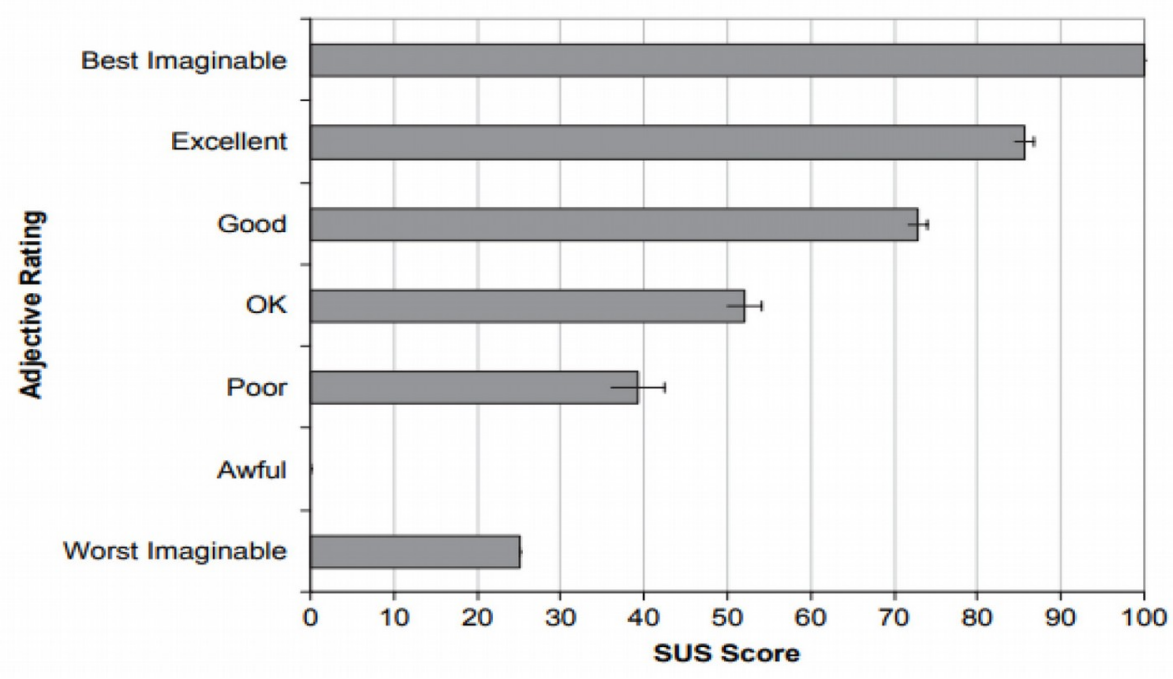

Figure 3. Mean system SUS scores rating (Bangor et al., 2008)

The group that used Google Plus achieved a total score of 4017.5, an average of 80.35 points on the SUS, which is rated as excellent. The third experimental group, which used Google Classroom, had a total of 4322.5 and an average score of 86.45 ; this score is classified as excellent. Based on the previous results, there was some convergence in the usability of the three environments, and they were at an acceptable level. From the above, the first research question can be answered by stating that Google cloud applications (Google Drive, Google Plus, and Google Classroom) have appropriate levels of usability. The results showed that the Google Classroom environment was at the first level, followed by the Google Plus environment and the Google Drive environment.

\subsection{The Impact of the Applications on Students' Achievements}

The aim of this section is to answer the second research question. Table 5 shows a comparison of the averages between the experimental and control groups in the post-test. The ANOVA test was used to test the differences in the averages between study groups. The results showed statistically significant differences between the results of the three experimental groups and the control group, as shown in Table $5($ Sig $<0.05)$.

To determine the statistically significant differences, a post hoc test was applied to compare each group with the other groups. The results showed statistically significant differences between the control group and the experimental group that used the Google Classroom application, Sig $=0.34$, which is smaller than the function of 0.05 , as shown in the table below.

Thus, the second question can be answered by stating that there was a positive impact of the use of Google Cloud applications (Google Drive, Google Plus, and Google Classroom) on the academic achievement of Imam Abdulrahman Bin Faisal University students because the results showed an increase in the students' averages following the use of these applications. The results also showed statistically significant differences in favor of using the Google Classroom application compared to the traditional learning methods.

\begin{tabular}{|l|r|r|r|r|r|}
\hline \multicolumn{7}{|c|}{ ANOVA } & \multicolumn{1}{c|}{ Sig. } \\
\hline Between Groups & \multicolumn{1}{|c|}{ Sum of Squares } & df & Mean Square & F & \multirow{2}{*}{.036} \\
\cline { 1 - 3 } Within Groups & 1018.37 & 3 & 117.03 & 2.90 & \\
\hline Total & 22939.22 & 196 & & \\
\hline
\end{tabular}

Table 5. ANOVA test results 


\begin{tabular}{|c|c|c|c|c|c|c|}
\hline \multicolumn{7}{|c|}{ Sidak } \\
\hline \multirow[b]{2}{*}{ (I) VAR00002 } & \multirow[b]{2}{*}{ (J) VAR00002 } & \multirow[b]{2}{*}{$\begin{array}{c}\text { Mean Difference } \\
(\mathrm{I}-\mathrm{J})\end{array}$} & \multirow[b]{2}{*}{$\begin{array}{l}\text { Std. } \\
\text { Error }\end{array}$} & \multirow[b]{2}{*}{ Sig. } & \multicolumn{2}{|c|}{$95 \%$ Confidence Interval } \\
\hline & & & & & $\begin{array}{l}\text { Lower } \\
\text { Bound }\end{array}$ & Upper Bound \\
\hline \multirow{3}{*}{ Google Classroom } & Google+ & 2.06 & 2.16 & .91 & $-3.69-$ & 7.81 \\
\hline & Google Drive & 1.28 & 2.16 & .99 & $-4.47-$ & 7.03 \\
\hline & Control Group & 6.04 & 2.16 & .03 & .28 & 11.79 \\
\hline \multirow{3}{*}{ Google+ } & $\begin{array}{l}\text { Google } \\
\text { Classroom }\end{array}$ & $-2.06-$ & 2.16 & .91 & $-7.81-$ & 3.69 \\
\hline & Google Drive & $-.78-$ & 2.16 & 1 & $-6.53-$ & 4.97 \\
\hline & Control Group & 3.98 & 2.16 & .34 & $-1.77-$ & 9.73 \\
\hline \multirow{3}{*}{ Google Drive } & \begin{tabular}{|l|} 
Google \\
Classroom
\end{tabular} & $-1.28-$ & 2.16 & .99 & $-7.03-$ & 4.47 \\
\hline & Google+ & .78 & 2.16 & 1 & $-4.97-$ & 6.53 \\
\hline & Control Group & 4.76 & 2.16 & .16 & -.99 & 10.51 \\
\hline \multirow{3}{*}{ Control Group } & $\begin{array}{l}\text { Google } \\
\text { Classroom }\end{array}$ & $-6.04-$ & 2.16 & .03 & $-11.79-$ & $-.28-$ \\
\hline & Google+ & $-3.98-$ & 2.16 & .34 & $-9.73-$ & 1.77 \\
\hline & Google Drive & $-4.76-$ & 2.16 & .16 & $-10.51-$ & .99 \\
\hline
\end{tabular}

Table 6. Multiple Comparisons results

\section{Discussion}

These results can be explained by the fact that the students in the group that studied using the Google Classroom environment felt that it was more usable in the cloud educational environment than did the students who studied using Google Drive and Google Plus. The results also showed a limited increase in the perceived usability of Google Plus over Google Drive. This is consistent with many studies' findings pertaining to the effectiveness of usability in the multiple research variables applied in learning environments and platforms across Web networks, including the works of Rafla, Robillard and Desmarais (2006) and Van and Ling (2008). These authors concluded the existence of effectiveness when designing learning elements across websites, as well as an increase in usability because of the easy navigation for the user and rapid access to the desired section of the website. Previous studies also reported on the importance of meeting the students' needs and making the most of the benefits of Internet cloud applications, particularly if these environments provide active effects and interactions that increase students' interest (Alon \& Herath, 2014; Fang \& Holsapple, 2007).

The results of this study indicate that the Google Classroom environment was considered to have a much higher level of usability than did the other environments. The study also showed a positive impact on the scholastic achievement of the students. This may be because Google Classroom has many advantages that can easily be used in educational institutions, is completely free, and includes the principles and strategies of e-learning based on the principle of blended learning, which is based on the integration of learning in a classroom with a teacher and learning via the Internet. The teacher and the students can use it to facilitate learning in a classroom by using the available learning techniques in the environment. This is consistent with Almishikis (2017) finding that the environment also has other advantages because it is primarily designed to serve the educational process. One of the advantages of the Google Classroom environment (Fralinger \& Owens, 2009; Krauskopf et al., 2012) is the Homework feature, which allows the teacher to assign homework to the students, evaluate their work, and provide them with direct feedback.

The cloud applications Google Plus and Google Drive achieved user-acceptable levels and facilitated a slight increase in the students' achievements. This could have been because these applications are not directly intended for the education field, although their features can be used to assist in the education process. 
In general, the study is consistent with previous studies pertaining to the role of cloud storage environments in increasing the level of students' achievements and developing and facilitating the learning process through many of the features provided, including flexibility, interaction, multimedia, observing individual differences, multilingualism, and open and multiple access to information (Rahman, 2016; Jakkaew \& Hemrungrote 2017; Kumar \& Bervell, 2019).

Studies such as those by Zhou, Fang, Vogel, Jin and Zhang (2012) have indicated the enthusiasm of educational communities and their desire to employ technical means in the teaching and learning processes. Banerjee and Dey (2013) also addressed the factors that support the employment of cloud social networks such as Google Plus in learning, as they provide rich and valuable content and are designed to increase users' confidence. Nevin (2009) also noted that Google Cloud applications supported the most important trends in the field of education technology, namely cloud computing and mobile education, which contribute to reducing the loss of work and save time and effort by providing rapid access to the required information.

\section{Conclusion and Future Work}

This study discussed the use of cloud computing environments (Google Classroom, Google Plus, and Google Drive) and demonstrated usability by implementing the SUS for usability. The study concluded the importance of applying Google Classroom and the high level of usability that was achieved, as well as the statistical increase it generated in the students' results. The study therefore recommends that these cloud storage technologies be integrated into education and that teachers and learners receive sufficient training to use them. The study also encourages teachers to use Google applications in their daily tasks and the research required from them. The study also recommends utilizing the results of the current research at the applied level, particularly if future research supports these results.

Furthermore, a comparative study on students' and faculties' perceptions toward Google Classroom acceptance could be studied in depth in order to develop a framework for adopting this application in higher education using best practice.

\section{Declaration of Conflicting Interests}

The authors declared no potential conflicts of interest with respect to the research, authorship, and/or publication of this article.

\section{Funding}

The authors received no financial support for the research, authorship, and/or publication of this article.

\section{References}

Aaron, L., \& Roche, C., (2012). Teaching, Learning and Collaborating in the Cloud: Applications of Cloud Computing for Educators in Post-Secondary Institutions. Journal of Educational Technology Systems, 40(2), 95-111. https://doi.org/10.2190/ET.40.2.b

Alhamdi, F.A., \& Khaparde, V. (2014). Collaboration in the Could Computing among Students of Library and Information Science Department. International Journal of Advanced Library and Information Science, 2(1), 82-92.

Alraimi, K.M., Zo, H., \& Ciganek, A.P. (2015). Understanding the MOOCs continuance: The role of openness and reputation. Computers \& Education, 80, 28-38. https://doi.org/10.1016/j.compedu.2014.08.006

Al-Maroof, R.A.S., \& Al-Emran, M. (2018). Students acceptance of Google classroom: an exploratory study using PLS-SEM approach. International Journal of Emerging Technologies in Learning (IJET), 13(06), 112. https://doi.org/10.3991/ijet.v13i06.8275 
Al-Mani, A.A. (2005). Learning Styles Preferred by Middle School Students in Riyadh. Jordan university Journal of Educational Studies.

Almishiki, A. (2017). Using Electronic Classrooms in Training: Experimenting with Google Classroom, Available at: https://www.mozn.ws/13950/

Alon, I., \& Herath, K. (2014). Teaching international business via social media projects. Journal of Teaching in International Business, 25(1), 44-59. https://doi.org/10.1080/08975930.2013.847814

Bagish, S.S.A. (2014). Students Awareness of Could Computing: Case Study Faculty of Engineering at Aden University. International Journal of Engineering Development and Research, 2(1), 1122-1129.

Bai, Y., Shen, S., Chen, L., \& Zhuo, Y. (2011). Cloud learning: A new learning style. International Conference on Multimedia Technology (3460-3463). Hangzhou, China.

Banerjee, N., \& Dey, A.K. (2013). Identifying the factors influencing users' adoption of social networking websites-A study on facebook. International Journal of Marketing Studies, 5(6).

https://doi.org/10.5539/ijms.v5n6p109

Bangor, A., Kortum, P.T., \& Miller, J.T. (2008). An empirical evaluation of the system usability scale. International Journal of Human-Computer Interaction, 24(6), 574-594.

https://doi.org/10.1080/10447310802205776

Bell, J. (2014). Doing Your Research Project: A guide for first-time researchers. UK: McGraw-Hill Education.

Bhatia, G., \& Lala, A. (2012). Implementation of Cloud Computing technology in Indian education system, Computing Communication \& Networking Technologies (ICCCNT), Third International Conference $(1-5)$.

Brooke, J. (1996). SUS-A quick and dirty usability scale. Usability Evaluation in Industry, 189(194), 4-7.

Bryman, A., \& Cramer, D. (2012). Quantitative data analysis with IBM SPSS 17, 18 \& 19: A guide for social scientists. Routledge, Psycholofy Press. https://doi.org/10.4324/9780203180990

Carmel, M., \& John, L. (2009). Usability and Usefulness of E. Book on PPCs: How Students, Opinions Vary Over Time, Australasian Journal of Educational Technology, 25(1).

Chauhan, A. (2014). Massive open online courses (MOOCS): Emerging trends in assessment and accreditation. Digital Education Review, 25, 7-17.

Cidral, W.A., Oliveira, T., Di Felice, M., \& Aparicio, M. (2018). E-learning success determinants: Brazilian empirical study. Computers \& Education, 122, 273-290. https://doi.org/10.1016/j.compedu.2017.12.001

Crompton, H. (2013). A historical overview of mobile learning: Toward learner-centered education. In Z.L. Berge \& L.Y. Muilenburg (Eds.), Handbook of mobile learning (pp. 3-14). New York: Routledge.

Crompton, H., \& Burke, D. (2018). The use of mobile learning in higher education: A systematic review. Computers \& Education, 123, 53-64. https://doi.org/10.1016/j.compedu.2018.04.007

Dawson, C. (2009). Introduction to research methods: A practical guide for anyone undertaking a research project. Oxford: How To Books Ltd.

Doan, D. (2014). A Developer's Survey on Different Cloud Platforms. San Diego, USA: University of California.

Doelitzscher, F., Sulistio, R., Reich, C., Kuijs, H., \& Wolf, D. (2011). Private cloud for collaboration and elearning services: from Iaas to Saas. Computing, 91(1), 23-42. https://doi.org/10.1007/s00607-010-0106-z

Ercan, T. (2010). Effective use of cloud computing in educational institutions. Procedia Social and Behavioral Sciences, 2(2), 938-942. https://doi.org/10.1016/j.sbspro.2010.03.130 
Fang, X., \& Holsapple. W. (2007). An empirical study of web site navigation structures' impacts on web site usability. Decision Support Systems, 43(2), 476-491. https://doi.org/10.1016/j.dss.2006.11.004

Fernandez, A., Peralta, D., Benitez, J.M., \& Herrera, F. (2014). E-learning and educational data mining in cloud computing: an overview. International Journal of Learning Technology, 9(1), 25-52.

https://doi.org/10.1504/IJLT.2014.062447

Fralinger, B., \& Owens, R. (2009). YouTube as a learning tool. Journal of College Teaching \& Learning, 6(8), $15-28$.

Google (2009). Free email and collaboration tools for your school. In Google apps education edition. Available at: http://vww.google.com/a/help/intl/en/edu/index.html

Halash, E.A. (2013). Mobile Cloud Computing: Case Studies. Michigan, USA: Wayne State University.

Hammadi, A., (2017). Starting from today: Google classroom is free platform for everyone. Available at: https://www.mozn.ws/11553/

Huang, J.H., Lin, Y.R., \& Chuang, S.T., 2007. Elucidating user behavior of mobile learning: A perspective of the extended technology acceptance model. The Electronic Library, 25(5), 585-598.

https://doi.org/10.1108/02640470710829569

Jakkaew, P., \& Hemrungrote, S. (2017). The use of UTAUT2 model for understanding student perceptions using Google classroom: A case study of introduction to information technology course. 2017

International Conference on Digital Arts, Media and Technology (ICDAMT) (205-209). https://doi.org/10.1109/ICDAMT.2017.7904962

Kessler, G. (2012). Collaborative Writing among Second Language Learners in Academic Web-Based Projects. Language Learning \& Technology, 16(1), 91-109.

Khalifa, Z.M., \& Abdumunim, A.F. (2016). The Impact of Different Size Groups Sharing in the Cloud Computing Environment. Arabic Studies in Education and Psychology.

Khamis, M.A. (2009). Teaching and learning technology. Cairo: Dar Al Sahab Publishing \& Distribution Library.

Kothari, C.R. (2004). Research methodology: Methods and techniques. New Age International.

Krauskopf, K., Zahn, C., \& Hesse, F.W. (2012). Leveraging the affordances of Youtube: the role of pedagogical knowledge and mental models of technology functions for lesson planning with technology. Computers \& Education, 58(4), 1194-1206. https://doi.org/10.1016/j.compedu.2011.12.010

Kumar, J.A., \& Bervell, B. (2019). Google Classroom for mobile learning in higher education: Modelling the initial perceptions of students. Education and Information Technologies. https://doi.org/10.1007/s10639018-09858-z

Lahoti, A.A., \& Ramteke, P.L., (2014). Mobile Cloud Computing the Necessity of Future with its Architecture Advantages and Applications. International Journal on Recent and Innovation Trends in Computing Networks (IJCN), 3(5), 247-255.

Mariya, S. (2011). Cloud computing-an advanced e-learning platform of school education? In Interactive Collaborative Learning International Conference (569-570). https:/ / doi.org/10.1109/ICL.2011.6059651

Martins, A.I., Rosa, A.F., Queiros, A., Silva, A., \& Rocha, N.P. (2015). European Portuguese Validation of the System Usability Scale (SUS). Procedia Computer Science, 67, 293-300.

https://doi.org/10.1016/j.procs.2015.09.273

Nevin, R. (2009). Supporting 21 st century learning through Google Apps. Teacher Librarian, 37(2), 35-38. 
Oliver, E. (2018). Blended learning for teaching Theology. Verbum et Ecclesia, 39(1), e1-e7. https://doi.org/10.4102/ve.v39i1.1894

Ovadia, S. (2011). An early introduction to the Google+ social networking project. Behavioral Social Sciences Librarian, 30 (4), 259-263. https://doi.org/10.1080/01639269.2011.622258

Rafla, T., Robillard, N., \& Desmarais, M. (2006). Investigating the impact of usability on software architecture through scenarios: A case study on Web systems. Journal of Systems and Software. 415-426. https://doi.org/10.1016/j.jss.2005.10.014

Rahman, H. (2016). ICT Integration in Education: Potential and Challenges in IGI Global. In Human Development and Interaction in the Age of Ubiquitous Technology, 25-47.

Schmid, R.F., Bernard, R.M., Borokhovski, E., Tamim, R.M., Abrami, P.C., Surkes, M.A., et al. (2014). The effects of technology use in postsecondary education: A meta-analysis of classroom applications. Computers \& Education, 72, 271-291. https://doi.org/10.1016/j.compedu.2013.11.002

Sherer, P., \& Shea, T. (2011). Using online video to support student learning and engagement. College Teaching, 59(2), 56-59. https://doi.org/10.1080/87567555.2010.511313

Shi, Y., Yang, H.H., Yang, Z., \& Wu, D. (2014). Trends of Cloud Computing in Education. Hybrid Learning. Theory and Practice. ICHL 2014, Lecture Notes in Computer Science Springer. Cham. https://doi.org/10.1007/978-3-319-08961-4_12

Tugrul, T.O. (2012). Student perceptions of an educational technology tool: Video recordings of project presentations. Procedia-Social and Behavioral Sciences, 64, 133-140. https://doi.org/10.1016/j.sbspro.2012.11.016

Van, P., \& Ling, J. (2008). Modelling user experience with web sites: Usability, hedonic value, beauty and goodness. Science Direct. 20(3), 419-432.

Wheeler, B. \& Waggener, S. (2009). Above-campus services: shaping the promise of cloud computing for higher education. Educause Review, 44(6), 52-67.

Wu, T-T., Wang, C-S., Huang, S-H., \& Ciung, M-Y. (2012). Using Google plus to Conduct High Interaction and Interdependence Learning Environments Based on Group Investigation Strategy. Journal of Internet Technology, 997-1004.

Zhou, Z., Fang, Y., Vogel, D. R., Jin, X., \& Zhang, X. (2012). Attracted to or locked in? predicting continuance intention in social virtual world services. Journal of Management Information Systems, 29(1), 273-306. https://doi.org/10.2753/MIS0742-1222290108

\author{
Published by OmniaScience (www.omniascience.com) \\ Journal of Technology and Science Education, 2019 (www.jotse.org)
}

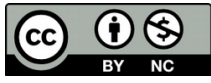

Article's contents are provided on an Attribution-Non Commercial 4.0 Creative commons International License.

Readers are allowed to copy, distribute and communicate article's contents, provided the author's and JOTSE journal's names are included. It must not be used for commercial purposes. To see the complete licence contents, please visit https://creativecommons.org/licenses/by-nc/4.0/. 